\title{
Bacterial Cellulose/Collagen Hydrogel for Wound Healing
}

\author{
Paula Rodrigues Fontes de Sousa Moraes ${ }^{a}$, Sybele Saska ${ }^{c}$, Hernane Barud ${ }^{c, d}$, \\ Laís Roncalho de Limac, Virgínia da Conceição Amaro Martinse, Ana Maria de Guzzi Plepisa,e, \\ Sidney José Lima Ribeiroc, Ana Maria Minarelli Gaspar ${ }^{a, b}$
}

aPrograma de Pós Graduação Interunidades Bioengenharia- EESC/FMRP/IQSC- USP, Av. Trabalhador São-carlense, 400, Arnold Schimidt, CEP: 13566-590, São Carlos, SP, Brazil

${ }^{b}$ Laboratório de Morfologia, Universidade Estadual Paulista - UNESP, Rua Humaitá, 1680, Centro, CEP: 14801-903, Araraquara, SP, Brazil

'Instituto de Química - Universidade Estadual Paulista - UNESP, Rua Prof. Francisco Degni, 55, Quitandinha, CEP: 14800-060, Araraquara, SP, Brazil

${ }^{d}$ Laboratório de Biopolimeros e Biomateriais (BioPolMat), Centro Universitário de Araraquara UNIARA, Rua Voluntários da Pátria, 1309, Centro, CEP: 14801-320, Araraquara, SP, Brazil eInstituto de Química de São Carlos/USP, Av. Trabalhador São-carlense, 400, Arnold Schimidt, CEP: 13566-590, São Carlos, SP, Brazil

Received: May 5, 2015; Revised: October 15, 2015; Accepted: November 20, 2015

\begin{abstract}
This study compares a wound dressing based on bacterial cellulose/collagen (BC/COL) hydrogel in rat dorsum with commercial collagenase ointment and untreated wound. The hydrogel was characterized by Scanning Electron Microscopy (SEM), Thermogravimetric Analysis (TGA), Fourier transformed - Infrared spectroscopy (FT-IR) and X-ray diffraction (XRD). According to the In vivo test and macroscopic evaluation, $\mathrm{BC} / \mathrm{COL}$ hydrogel showed a better repair of wounds and promoted statistically significant differences of tissue repair between treatments on the 7th day after surgery. Better quality, quantity and orientation evaluation of collagen fibers $(\mathrm{p}=0.0001)$ were observed in the $\mathrm{BC} / \mathrm{COL}$ hydrogel and collagenase ointment groups in relation to the control group. The $\mathrm{BC} / \mathrm{COL}$ hydrogel promoted better wound healing than collagenase and the control group, therefore, it can be considered a potential wound dressing for skin regeneration.
\end{abstract}

Keywords: bacterial cellulose, collagen, hydrogel, wound dressing, tissue repair

\section{Introduction}

Skin provides a natural barrier against the environment and performs a variety of essential protective functions ${ }^{1,2}$. However, it is the most frequently injured part of the human body. When it is hurt, the connective tissue becomes exposed and a series of local-cellular and biochemical events are triggered to repair its integrity.

The inflammation stage begins immediately after injury, first with vasoconstriction, which favors homeostasis and releases inflammation mediators. The proliferative phase is characterized by an angiogenesis process and proliferation of the granulation tissue, formed mainly by fibroblasts ${ }^{3,4}$.

The early healing promotes the coagulation of blood and is completed by the remodeling of the cell layers of the skin. When an injury occurs, the vascular integrity of the area is disrupted and blood extravasates to the surrounding tissue or plasma, where the damage is minor $^{5}$. The healing process is activated when platelets have come into contact with the exposed collagen, which leads to their aggregation and release of clotting factors. Such a process results in is

*E-mail: paularfsm@usp.br the deposition of a fibrin clot at the site of the injury ${ }^{6}$. Factors that influence the healing process are believed to also influence the final aspect of the scar.

Biocompatibility is the basic requirement for a material to be used for tissue repair. Biodegradability is also one of the most important biological properties, therefore, significant advances have been made for the development of resorbable polymers.

Alternative methods for wound healing have been developed and refined over the past decades. Some forms of treating chronic wounds include debridement, irrigation, administration of antibiotics, tissue grafts, and use of proteolytic enzymes ${ }^{7}$.

Wound dressings play a substantial role in the healing of certain types of open wounds (e.g. traumatic, thermal or chronic), unless the moist, warm and nutritious environment of wound beds provides an ideal condition for microbial growth. Therefore, the wound healing process can be interfered by bacterial colonization and subsequent infection, which may cause an excessive and prolonged inflammatory response from the host tissues ${ }^{8}$. 
In comparison with other biopolymers, such as collagen, chitosan and gelatin, bacterial cellulose (BC) displays excellent biological properties for tissue regeneration, mainly for the treatment of chronic and burn wounds ${ }^{9,10}$. It is produced as never-dried membranes free of lignin and hemicelluloses, which show high elastic modulus and tensile strength when wet ${ }^{11}$. Since the 80 s and 90 s, BC-based dressings (as Biofill ${ }^{\circledR}$ (Fibrocel, Brazil)) have been used as temporary dressings for the treatment of skin wounds mainly in burns, graft and chronic ulcers. In comparison to other wound dressings, Biofill ${ }^{\circledR}$ has shown positive indications of biocompatibility, immediate pain relief and consequent decrease in the post-surgery discomfort, faster healing with absence or appearance of scars, and a significant reduction in the time and cost of treatments. Moreover, it protects the wound against infections and is permeable to liquids and gases, acting as a suitable artificial skin ${ }^{9,12-17}$.

Collagen provides strength, integrity, and structure to normal tissues. When tissues are injured, its synthesis is required for repairs in defects, anatomical structure and functions. It is also one of the most common materials used for tissue repair because of its biological properties and ability to promote wound healing and an important component of the extracellular matrix ${ }^{18}$.

Collagenase is an enzyme that breaks the peptide bonds of collagen. It can be extracted from the culture of Clostridium histolyticum and is commonly used in therapies to remove cellular debris and extracellular tissue necrosis ${ }^{19,20}$. Its use in the treatment of wounds, ulcers and bedsores promotes new tissue formation and re-epithelialization and does not affect the healthy collagen and newly formed tissue ${ }^{21}$. Several pharmaceutical forms for its therapeutic application, such as cream, ointment and sterile unguent are available ${ }^{22}$.

Although various materials can be used for wound repair, the healing occurs in different ways ${ }^{23}$. However, no low-cost and effective dressing to prevent long hospitalizations of patients has been obtained.

This manuscript addresses the preparation and characterization of a new wound dressing based on bacterial cellulose/collagen (BC/COL) hydrogel and its respective application to wound healing in rats.

\section{Materials and methods}

\subsection{Preparation of $B C / C O L$ Hydrogel}

Bacterial cellulose (BC) membranes were obtained from cultures of Gluconacetobacter hansenii (ATCC 23769 strain). G. hansenii bacteria were cultivated in $100 \mathrm{~mL}$ flasks with a $20 \mathrm{~mL}$ static culture medium for $120 \mathrm{~h}$ at $28{ }^{\circ} \mathrm{C}$. The nutrient medium contained $2 \mathrm{wt} \%$ glucose, $0.5 \mathrm{wt} \%$ peptone, $0.5 \mathrm{wt} \%$ yeast extract, $0.27 \mathrm{wt} \%$ disodium hydrogen phosphate, and $0.115 \mathrm{wt} \%$ citric acid. Bacterial cellulose pellicles formed on the air/liquid interface were harvested and purified by immersion in a $2 \mathrm{wt} \% \mathrm{NaOH}$ solution at $80^{\circ} \mathrm{C}$ for $1 \mathrm{~h}$. Subsequently, they were immersed in a $1 \mathrm{wt} \% \mathrm{NaClO}$ solution for $30 \mathrm{~min}$, washed with deionized water and sterilized by autoclave at $120^{\circ} \mathrm{C}$ for $15 \mathrm{~min}$.
Type I collagen was obtained from bovine tendon pieces of approximately $1 \mathrm{~cm}$, according to the methodology by Goissis $^{24}$. Such pieces were treated with acetone for the removal of adipose tissue. $5 \mathrm{~g}$ of tendon were washed with distilled water and immersed into a $10 \mathrm{wt} \% \mathrm{NaCl}$ solution for $24 \mathrm{~h}$ at $4{ }^{\circ} \mathrm{C}$. The tendon was then washed with distilled water and immersed in $0.02 \mathrm{~mol} \mathrm{~L}^{-1}$ citrate buffer $(\mathrm{pH} 4.3)$ for $48 \mathrm{~h}$ at room temperature (RT) for the swelling of the tissue, which was subsequently homogenized in $500 \mathrm{~mL}$ of a $0.5 \mathrm{~mol} \mathrm{~L}^{-1}$ acetic acid solution containing pepsin at a 1:50 (w:w) ratio in relation to the initial weight of the tendon. A gel was formed and maintained for $24 \mathrm{~h}$ at $4{ }^{\circ} \mathrm{C}$. The protein was precipitated by the salting out method and $5 \mathrm{wt} \%$ of an $\mathrm{NaCl}$ solution were added. The precipitated collagen was dialyzed against distilled water for $72 \mathrm{~h}^{25}$.

$\mathrm{BC} / \mathrm{COL}$ hydrogel was prepared with sterilized instruments and $\mathrm{BC}$ membranes by autoclave and the solutions were sterilized by filtration in a Millipore ${ }^{\circledR}$ system.

Never-dried BC membranes were triturated in an aqueous medium by a high-speed disperser element type Ultra Turrax T18 Ika. The BC particles suspension was sieved (37 mesh) for the removal of excess of water. The BC pulp was used in the preparation of the BC/COL hydrogel. Subsequently, 0.2 wt\% Nipagin ${ }^{\circledR}$ (Henri Farma, Brazil) were solubilized in $5 \mathrm{wt} \%$ propyleneglycol (Pharma Nostra, Brazil) under orbital shaking at $50{ }^{\circ} \mathrm{C}$. The mixture was poured into a beaker containing $10 \mathrm{wt} \%$ bacterial cellulose pulp under mechanical stirring at RT. $3 \mathrm{wt} \%$ Natrosol (Hydroxyethylcellulose) (Pharma Nostra, Brazil) were slowly added under shaking until the obtaining of gel consistency at RT. Finally, $8 \mathrm{wt} \%$ collagen and deionized water were added to the gel under shaking for $3 \mathrm{~min}$ at RT. The BC/COL hydrogel was stored in a sterile vial.

\subsection{Physicochemical Characterization}

\subsubsection{Scanning Electron Microscopy (SEM)}

SEM images were obtained by a JEOL/EO - JSM-6610 scanning electron microscope for the analysis of changes in the microfibrilar structure in lyophilized samples. The samples were coated with a $10 \mathrm{~nm}$ carbon layer by a metallizer Balsers model CDS 050. The morphology was observed at an accelerating voltage of $15 \mathrm{kV}$.

\subsubsection{Thermogravimetric Analysis (TG)}

The themogravimetric curves of the samples were recorded by a TA SDT 2960 from TA Instruments Co. All samples were heated in alumina pans at a $25{ }^{\circ} \mathrm{C}$ to $800{ }^{\circ} \mathrm{C}$ temperature range under nitrogen atmosphere (flow rate of $100 \mathrm{~mL} \mathrm{~min}^{-1}$ ) and $10{ }^{\circ} \mathrm{C} \mathrm{min}^{-1}$ heating rate.

\subsubsection{X-ray Diffraction (XRD)}

$\mathrm{X}$-ray diffraction patterns of pure collagen, $\mathrm{BC}$ and $\mathrm{BC} / \mathrm{COL}$ samples were run by a Kristalloflex Siemens diffractometer, with an $\mathrm{Ni}$ filter and $\mathrm{Cu}(\mathrm{KD})$ radiation. The angular scan ranged between $4^{\circ}$ and $70^{\circ}$ with $0.02 \mathrm{~s}$ (2 $\theta$ ) step and $3 \mathrm{~s}$ acquisition time. The peaks for $\mathrm{BC}$ were identified by ICDD - PDF - 2 (International Centre for Diffraction Data - Power Diffraction File-2) standard data base. 


\subsubsection{Fourier Transform Infrared (FT-IR)}

Fourier transform infrared (FT-IR) spectra were obtained with lyophilized powdered samples by a Perkin Elmer Spectrum 2000 spectrophotometer. Pellets were prepared from mixtures of the samples and $\operatorname{KBr}(1: 100$ in weight). Sixty-four scans were accumulated at a $1 \mathrm{~cm}^{-1}$ resolution in the 4000 to $400 \mathrm{~cm}^{-1}$ range.

\subsection{Animal Experimentation}

The experiment was approved by the Ethics Committee on Animal Experimentation at the Faculty of Pharmaceutical Sciences at Araraquara, UNESP, São Paulo, Brazil. Twenty-four adult male rats (Rattus norvegicus, albinus, Holtzman) weighing approximately $200 \mathrm{~g}$ were used and randomly allocated into three groups: two treatment groups - $\mathrm{BC} / \mathrm{COL}$ hydrogel (GI) and collagenase ointment (Kollagenase base, Cristália Laboratory, Brazil) (GII) - and a control group (GIII). Six animals were studied per group/period. The periods for macroscopic and histological analyses were $3,7,15$ and 30 days after the surgery. General anesthesia was induced by intramuscular injections of ketamine hydrochloride (25 mg kg-1; Agener União, Brazil) and xylazine hydrochloride (5 $\mathrm{mg} \mathrm{kg}^{-1}$; Bayer, Brazil). All surgical procedures followed standard aseptic protocols. After the shaving and preparation of the dorsal region, three wounds were made $(2 \mathrm{~cm}$ distance between them) in the medium line of the dorsal region with a circular scalpel of $6 \mathrm{~mm}$ diameter. The depth of the wound reached epidermis, dermis, hypodermis and muscular layers until fascia superficialis.

The BC/COL hydrogel wound dressing (GI) was applied in the superior wound. The wound in the middle region was filled with collagenase ointment (GII) and the inferior wound was filled only with a blood clot (GIII). The wound dressings were applied once per day in all treatment period.

The animals were transferred to separate cages properly isolated and identified and kept at controlled room temperature $\left(22 \pm 2{ }^{\circ} \mathrm{C}\right)$, humidity $(60-70 \%)$ and light (12 h light/dark cycles) under appropriate conditions of food, water and hygiene. Their recovery was monitored daily. In the immediate postoperative period, all animals received intraperitoneal administration of a single dose of $12.5 \mathrm{mg} \mathrm{kg}^{-1}$ tramadol analgesic (Medley Pharmaceutical Industry Ltda., Brazil).

After 3, 7, 15 and 30 days, four animals in each group were anesthetized again, according to the protocol, for macroscopic analysis and removal of wounds. Subsequently, they were euthanized with an intramuscular administration of Thiopentax (thiopental, $0.16 \mathrm{~mL} 100 \mathrm{~g}^{-1}$ body weight; Cristália).

\subsection{Macroscopic Analysis}

The wounds were macroscopically evaluated after 3,7 , 15 and 30 days after surgery. The diameter of the injured area was measured by a digital caliper. Differences were observed between the wounds treated with $\mathrm{BC} / \mathrm{COL}$ hydrogel (GI) and collagenase ointment (GII), and between $\mathrm{BC} / \mathrm{COL}$ hydrogel (GI) and the control group (GIII).
The quantitative data obtained were tested for normality by Lilliefors Test. The one-way ANOVA followed by the post-hoc $t$ test (LSD) were then applied for the evaluation of differences among the groups and effect of the follow-up period. All statistical analyses were performed with BioEstat 5.3 software. The level of statistical significance was established at $5 \%$.

The macroscopic analysis evaluated the redness in the wound region, presence of excessive exudate and humidity.

\subsection{Histological Analysis}

After euthanasia, the areas of the wounds were surgically removed, fixed in a Bouin solution for $48 \mathrm{~h}$ and processed according to the histological routine for light microscopy. The specimens were cut into semi-serial $6 \mu \mathrm{m}$ sections in the longitudinal direction of the skin and stained with hematoxylin-eosin (H\&E). They were analyzed and photographed under a microscope (Olympus X51; Olympus, WA) coupled to a digital camera (Olympus DP71, 12.5 Mpixels; Olympus) of $6.3 \times$ magnification. The images were captured by Leica Application Suite software.

Scores of inflammatory reaction evaluations were applied according to the inflammation degree (scores $0-4$ : 0 - no reaction; 1 - very slight reaction; 2 - mild reaction; 3 - moderate reaction; 4 - marked reaction) and the ASTM F981-04 standards ${ }^{26}$. The statistical analysis was descriptive and consisted in dividing the samples of each lamina according to the periods of 3, 7 and 15 days. Six laminas of each specimen with six cuts were analyzed. The first and last cuts were discarded.

The tissue repair pattern was also evaluated regarding quality, quantity and orientation of collagen fibers and epithelium regeneration. The scores used are shown in Tables 1 and 2.

The data obtained were tested for normality by Lilliefors Test. The Kruskal-Wallis test evaluated the inflammatory degree of the specimens and quantity and quality of collagen fibers among groups. The ANOVA test was used for the data of epithelium regeneration degrees. All analyses, conducted by BioEstat 5.3 software, were subjected to a post-hoc Dunn's test so that the differences between groups and the effect of the period on each group could be measured. The level of statistical significance was established at $5 \%$.

Table 1. Classification of the tissue repair pattern regarding quality, quantity and orientation of collagen fibers.

\begin{tabular}{cc}
\hline Classification & Score \\
\hline Absence & 0 \\
Disorganized fibers & 1 \\
Poorly organized fibers & 2 \\
Medium organization of fibers & 3 \\
Well organized fibers & 4 \\
\hline
\end{tabular}

Table 2. Classification of the tissue repair pattern in relation to the epithelial repair.

\begin{tabular}{cc}
\hline Classification & Score \\
\hline Unrepaired & 0 \\
Healing process & 1 \\
Repaired & 2 \\
\hline
\end{tabular}




\section{Results and Discussion}

\subsection{Physicochemical Characterization of BC/COL Hydrogel}

\subsubsection{Scanning Electron Microscopy (SEM)}

Figure 1 shows SEM images of lyophilized pure collagen and $\mathrm{BC} / \mathrm{COL}$ hydrogel, respectively. The $\mathrm{BC} / \mathrm{COL}$ hydrogel images display a porous material, typical of a hydrogel and the SEM micrographs show a structure of randomly disposed fiber arrangements, with some more compact points. The fibers exhibit an irregular morphology and appear more compact than those of collagen (Figures 1c and 1d). Interconnected pores in three-dimensional directions throughout the $\mathrm{BC} / \mathrm{COL}$ sample are extremely important for the tissue repair, as such morphology enables the ingrowth of fibroblasts ${ }^{27}$.

\subsubsection{Thermogravimetric Analysis (TG)}

The TG curves for pure collagen (a) BC/COL hydrogel (b) and pristine BC (c) are shown in Figure 2.

The Thermogravimetric analysis estimated the thermal stability and degradation profiles of all samples. The pure collagen, $\mathrm{BC} / \mathrm{COL}$ hydrogel and pure $\mathrm{BC}$ showed a first step formed by an initial smooth weight loss from room temperature up to $85^{\circ} \mathrm{C}(14 \%), 75^{\circ} \mathrm{C}(10 \%)$ and $245^{\circ} \mathrm{C}(8 \%)$, respectively, due to the loss of structural bound water ${ }^{28-30}$. Important weight losses were observed at approximately $325^{\circ} \mathrm{C}$ in the collagen and $\mathrm{BC} / \mathrm{COL}$ samples, attributed to the decomposition of both collagen and bacterial cellulose, and at around $355^{\circ} \mathrm{C}$ for the $\mathrm{BC}$ sample.

The onset temperature (Tonset) observed in the TG curve for the $\mathrm{BC} / \mathrm{COL}$ hydrogel revealed a $30{ }^{\circ} \mathrm{C}$ decrease in the thermal stability of $\mathrm{BC}$ in the presence of collagen.

The TG/DTG curves indicate the BC/COL hydrogel exhibits excellent thermal properties, despite a considerable change in its thermal stability after the incorporation of collagen. This decrease may be related to a decrease in the $\mathrm{BC}$ crystallinity after the preparation of the hydrogel, as observed in the XRD results, Figure 3.

\subsubsection{X-ray Diffraction (XRD)}

The XRD patterns for $\mathrm{BC} / \mathrm{COL}$ hydrogel, pure collagen and $\mathrm{BC}$ membrane are shown in Figure 3.

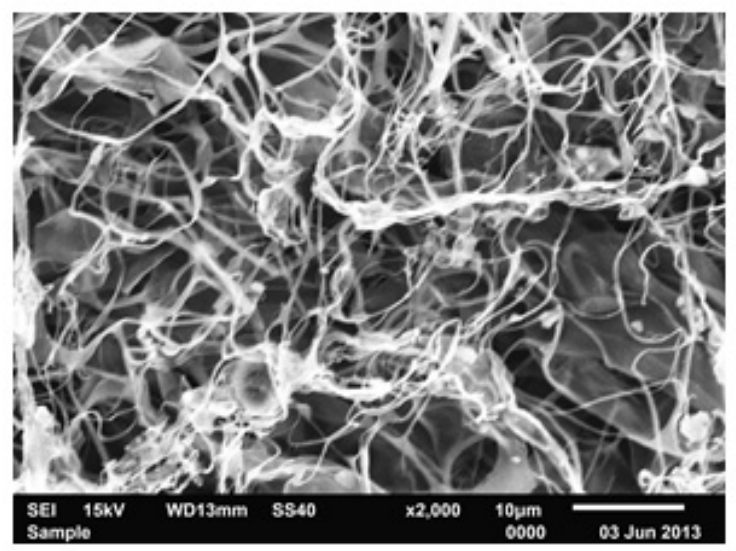

(a)

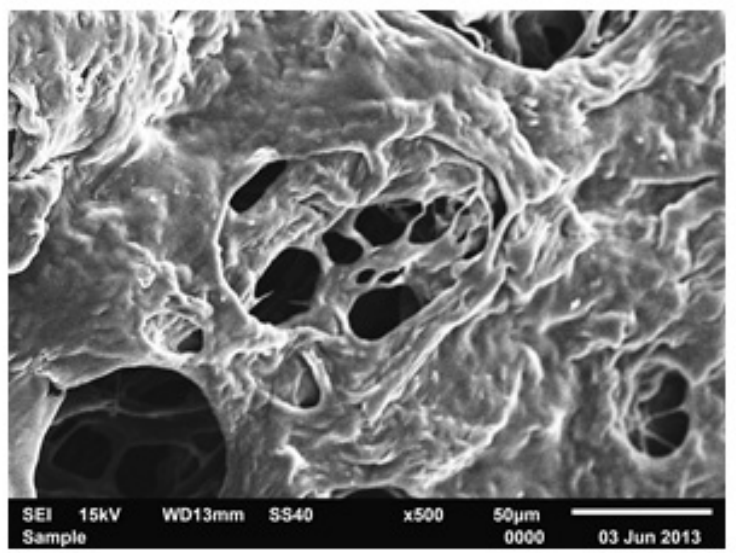

(c)

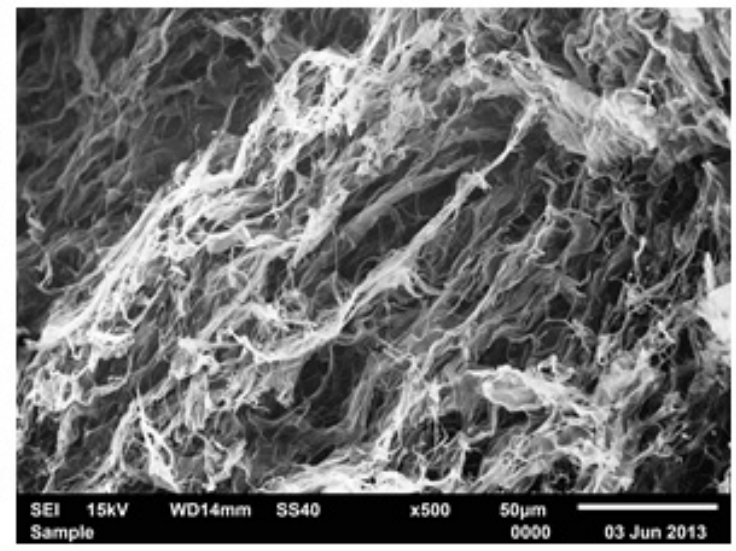

(b)

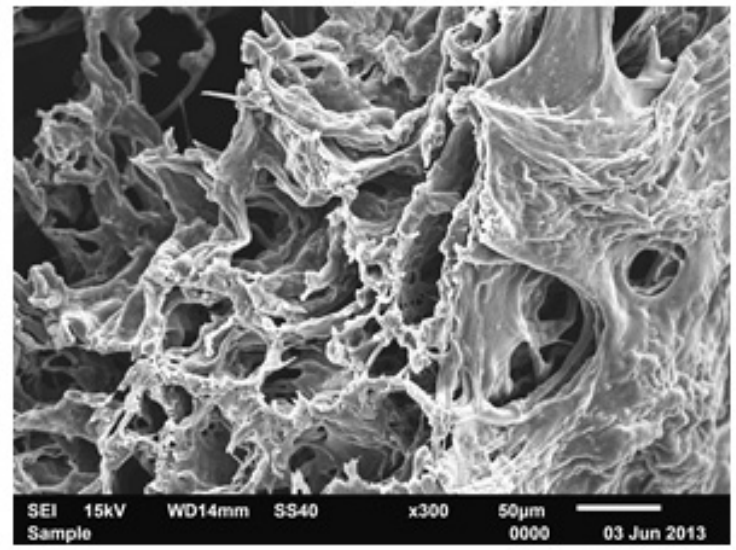

(d)

Figure 1. SEM surface images of pure collagen (a) and BC/COL hydrogel (c). SEM crosssection images of pure collagen (b) and BC/COL hydrogel (d). 
$\mathrm{BC}$ peaks were identified as native cellulose (ICDD PDF \# 50-2241, PDF-2, International Centre for Diffraction Data, Power Diffraction File-2) and characteristic peaks observed at $2 \theta=15^{\circ}$ and $22.5^{\circ}$ were attributed to the cellulose $1 \alpha$ and $1 \beta$ phases, respectively ${ }^{28,29}$. A semi-crystalline standard was observed for $\mathrm{BC}$ and a broad peak at the $2 \theta$ range $10^{\circ}-25^{\circ}$ was verified for the diffraction pattern of collagen (Figure $3 b$ ), whose characteristic is typical of pure collagen. All such features proved collagen a quite amorphous polymer ${ }^{31}$.
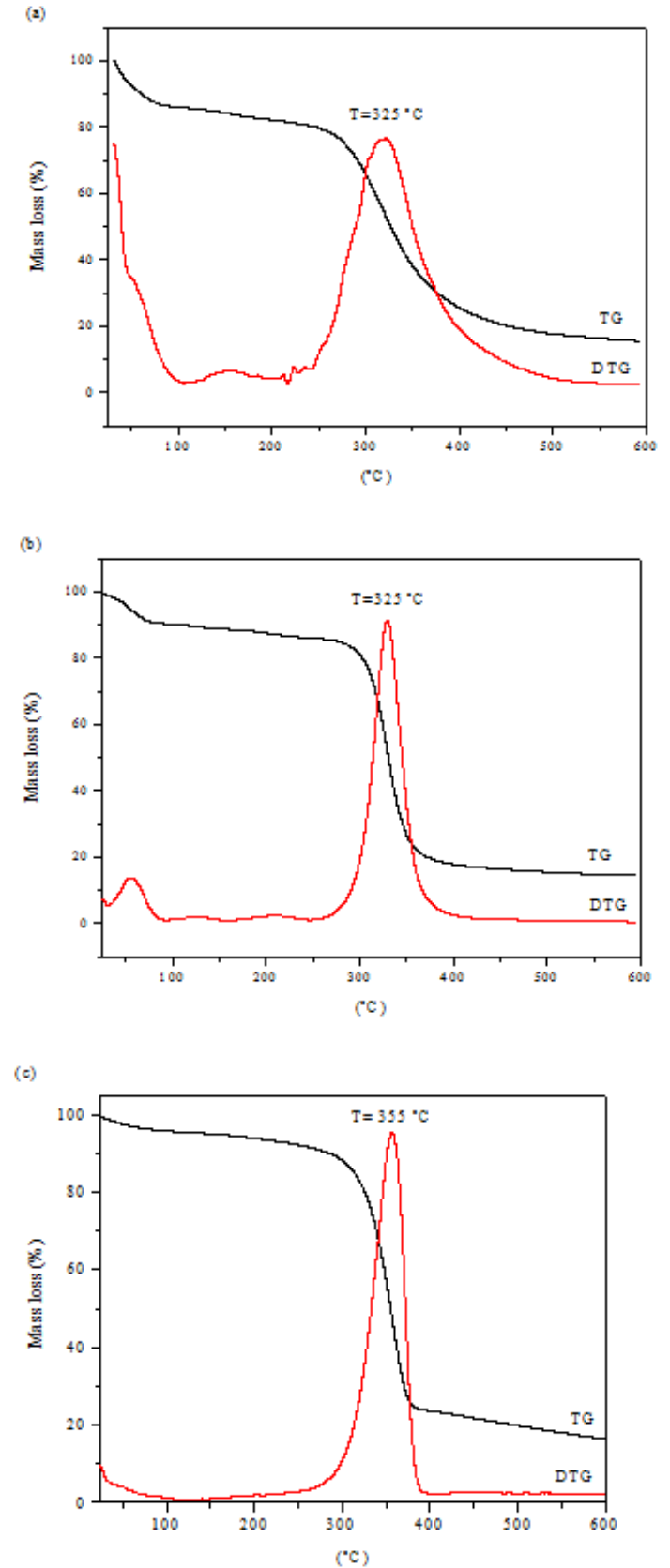

Figure 2. TG curves (----) and DTG (-----): (a) pure collagen, (b) $\mathrm{BC} / \mathrm{COL}$ hydrogel and (c) pristine $\mathrm{BC}$.
The XRD pattern of the $\mathrm{BC} / \mathrm{COL}$ hydrogel also showed a broad peak at $2 \theta=10^{\circ}-25^{\circ}$ and peaks at $2 \theta=15^{\circ}, 17^{\circ}$ and $25^{\circ}$ related to $\mathrm{BC}$. This result has confirmed the incorporation of collagen into $\mathrm{BC} / \mathrm{COL}$ hydrogel and also suggests a more amorphous profile than the XRD pattern for pure $\mathrm{BC}$. A decrease in the intensity of the pristine $\mathrm{BC}$ peaks may be attributed to the presence of collagen in the sample ${ }^{28}$.

\subsubsection{Fourier Transform Infrared (FT-IR)}

Figure 4 shows the FT-IR spectra of the lyophilized pure collagen, $\mathrm{BC} / \mathrm{COL}$ and pristine $\mathrm{BC}$ samples.

The integrity of the collagen structure could be verified by the relation between the relative absorbance intensity values of the bands, which should be near or equal to $1^{32,33}$. The absorbance intensity values of the bands at 1235 and $1450 \mathrm{~cm}^{-1}$ were 1.1690 and 1.1755 , respectively. Such bands were attributed to amide III and the $\mathrm{C}-\mathrm{H}$ bond of the pyrrolidine ring of proline and hydroxyproline ${ }^{34}$. Therefore, the extracted collagen revealed a ratio near 1 $(1.1690 / 1.1755=0.995)$, which proved the secondary

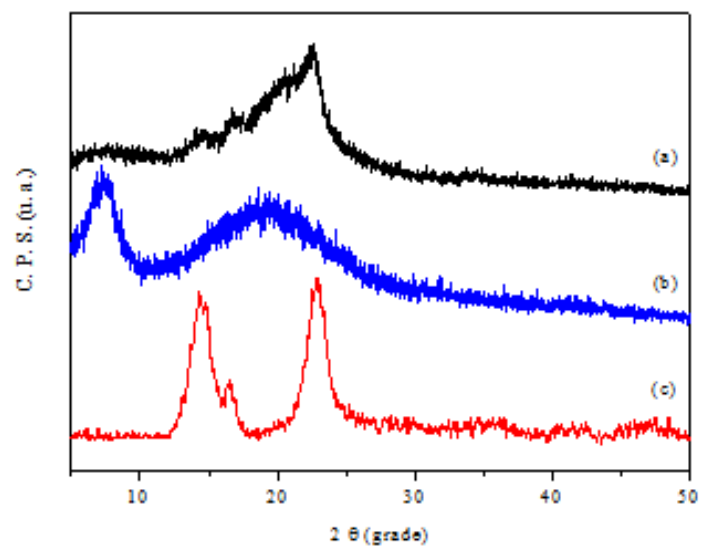

Figure 3. XRD diffraction patterns of the BC/COL hydrogel (a), pure collagen (b) and pristine BC (c).

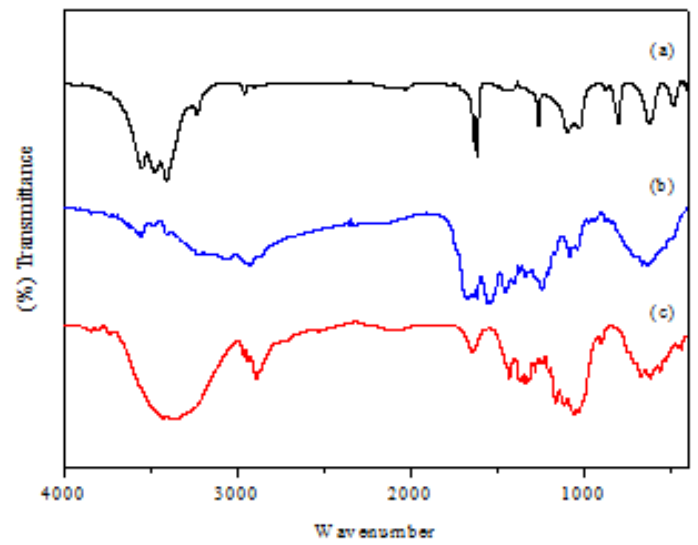

Figure 4. FT-IR spectra: (a) BC/COL hydrogel, (b) pure collagen and (c) pristine BC. 
structure (triple helix) was preserved during the collagen extraction process. If this ratio is not near the unit value (1), the collagen may be denatured (gelatin), which is not interesting for the study purpose.

Typical IR bands for pure collagen are shown in Figure 4 (b): N-H stretching at $\sim 3520 \mathrm{~cm}^{-1}$ and $3230 \mathrm{~cm}^{-1}$ for amide $\mathrm{A}, \mathrm{CH}_{2}$ asymmetric stretching at $\sim 2930 \mathrm{~cm}^{-1}$, $\mathrm{C}=\mathrm{O}$ stretching at $1670 \mathrm{~cm}^{-1}$ for amide $\mathrm{I}$, and $\mathrm{N}-\mathrm{H}$ bending at $1545 \mathrm{~cm}^{-1}$ for amide $\mathrm{II}^{28,34,35}$.

The BC spectrum showed typical bands for cellulose, such as $\mathrm{OH}$ stretching around $3450-3300 \mathrm{~cm}^{-1}, \mathrm{C}-\mathrm{H}$ stretching for alkanes and $\mathrm{CH}_{2}$ asymmetric stretching at $\sim 2895 \mathrm{~cm}^{-1}$, $\mathrm{H}-\mathrm{O}-\mathrm{H}$ bending of adsorbed water at $1640 \mathrm{~cm}^{-1}, \mathrm{CH}_{2}$ deformation at $1435 \mathrm{~cm}^{-1}, \mathrm{CH}_{3}$ deformation at $1370 \mathrm{~cm}^{-1}$, $\mathrm{OH}$ deformation at $1336 \mathrm{~cm}^{-1}$ and $\mathrm{C}-\mathrm{O}$ deformation at $1320-1030 \mathrm{~cm}^{-128,29}$.

Bands at 1450 and $1235 \mathrm{~cm}^{-1}$ were observed for the pure collagen spectrum. The BC/COL hydrogel spectrum showed slight differences in these bands. The band localized at $1439 \mathrm{~cm}^{-1}$ suffered a $11 \mathrm{~cm}^{-1}$ blue shift, and the one at $1260 \mathrm{~cm}^{-1}$ suffered a $20 \mathrm{~cm}^{-1}$ red shift, which also suggests interactions between $\mathrm{BC}$ and collagen. The change in the intensity of the bands in relation to the pure collagen spectrum may be due to the addition of other components to the hydrogel. No typical protein bands were observed at 1670 and $1545 \mathrm{~cm}^{-1}$ for the $\mathrm{BC} / \mathrm{COL}$ hydrogel, but for pure collagen.

\subsection{In Vivo Experiment}

Different types of wound dressings have been developed because of the existence of several types of acute and chronic wounds caused by multiple pathophysiologies, which affect the soft tissues in different chronicity levels and several phases of wound healing. Alternative methods of wound closure have been designed and refined over the past decades ${ }^{7}$. An ideal wound dressing should prevent exacerbated healing, promote no foreign body reaction, and be easily removed, if necessary, without damaging the newly formed tissue ${ }^{36}$.

Healing depends on two pillars, namely vascularization and capacity of the cell to synthesize collagen. Vascularization promotes the transport of cells to the inflammatory site and supply of nutrients and oxygen. Furthermore, epithelial integrity is an important parameter for the definition of time and effectiveness of second intention healing ${ }^{37}$. Several factors can influence any stage of healing. The principal local factors include bleeding, oxygen tension and infection. Some extrinsic factors are surgical technique, topical antiseptics and dressings ${ }^{38}$. Regarding wound dressings, several types have been developed based on plant herbs ${ }^{39,40}$, hydrocolloid, alginate and collagen ${ }^{41}$ and can be applied as ointment, film ${ }^{42}$, foam and gel ${ }^{43}$ for various purposes of treatment ${ }^{44}$.

This manuscript reports on the development of a wound dressing for tissue repair based on bacterial cellulose and type I collagen.

Hydrogels promote suitable physiological conditions for wound healing ${ }^{45}$ and a barrier against microorganisms and enable the permeation of only water and nutrients. They also retain water, therefore, a favorable environment for the wound must be maintained for tissue repair. Hydrogels have been indicated to the treatment of deep and contaminated wounds with high amounts of exudate ${ }^{46}$. Their soft and rubbery feature minimizes irritation in adjacent tissues ${ }^{47}$. All such characteristics favor the obtaining of efficient results when hydrogel is used for wound repair.

However, the BC/COL hydrogel showed an efficient wound dressing and promoted a faster and better re-epithelialization within 7-15 days of postoperative period in relation to other groups. It also improved adhesion and caused no complications during the healing period.

The macroscopic analysis aimed at the observation of a possible erythema near the region of the lesion, presence of excessive exudate and maintenance of humidity in the wound. The BC/COL hydrogel promoted a macroscopically better result of tissue repair in relation to wound dressing based on dextran hydrogel ${ }^{48}$, whereas the histological analysis showed similar results in comparison to the hydrogel based on chitin $^{49}$. It also exhibited most of the desirable characteristics for an 'ideal dressing', was suitable for the cleansing of dry wounds and promoted autolytic debridement. The hydrogel dressing was not reactive with the biological tissue, was permeable to metabolites, and promoted a decrease in the temperature of the wound bed, which may lead to a marked reduction in pain. It left no residue on the wound bed and improved the re-epithelialization of wounds ${ }^{50-52}$.

No group showed formation of purulent exudate on the wounds. Such exudate is a sign of exacerbated inflammatory response that may be caused by factors, such as infection on the site or failure of material due to its cytotoxiaty ${ }^{53}$.

The BC/COL hydrogel showed a wound dressing of easy application and good adhesion on the wound bed. The collagenase ointment showed more difficult for application due to its bad adhesion on the wound bed.

The mean values \pm standard error of the wound sizes in relation to the experimental periods and groups are shown in Figure 5. The values in percentage were based on a previous study conducted by Sanchez ${ }^{54}$.

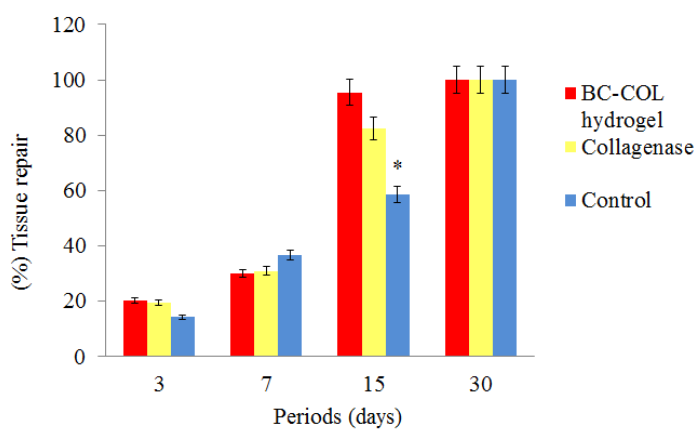

Figure 5. Values measured for the tissue repair of wounds of the GI, GII and GIII groups for experimental periods of 3, 7, 15 and 30 days. Values are expressed as mean \pm standard error; $* \mathrm{p}<0.05$. The one-way ANOVA followed by the post-hoc $t$ test (LSD) were applied. 
No exudate was observed in the wounds in the first days of the postoperative period. At day 3, all wounds showed a decrease in size in relation to the day of the surgery, however, only a small difference was visually perceived in comparison to the studied groups. The lesions remained clean and granulation tissue (mainly in the margins) was formed. No exudate, inflammatory reaction or apparent contamination (pus, edema and severe erythema) were observed.

At day 7, the granulation tissue had covered all the area of the wounds, mainly those treated with either hydrogel or ointment. In this period, all lesions decreased in size, however, the measured values revealed no statistically significant differences among the treatments and the control group ( $\mathrm{p}>0.05)$.

At day 15, the size of the wounds decreased and a complete reepithelization was observed in the 3 groups. A statistically significant difference was observed in the tissue repair among the groups $(\mathrm{p}=0.0025)$. The GI and GII groups showed no statistical difference $(\mathrm{p}>0.05)$, however, the $\mathrm{BC} / \mathrm{COL}$ hydrogel revealed a slight tendency for a better repair of wounds. The repair values for GI and GII were higher in comparison to the control group and statistically different, i.e., $\mathrm{p}=0.001$ and $\mathrm{p}=0.0117$, respectively. The results showed the $\mathrm{BC} / \mathrm{COL}$ hydrogel promoted a faster wound healing than the collagenase ointment and the control group.

At day 30, all wounds had been completely healed and no statistical differences were observed among the groups.

No sign of acute inflammatory response was observed in the animals treated with collagenase ointment. The bacterial cellulose dressings also promoted no exacerbation or prolongation of the inflammatory process because of their biological and physical properties and non-toxic, biocompatible and hydrophilic nature. An important aspect is the ability of the dressing to contain exudate in the wound and form a capsule to immobilize pathogenic microorganisms, which could promote an infectious process and consequent exacerbation and prolongation of inflammatory reactions.

At day 3, the wounds treated with BC-COL hydrogel (GI) showed a moderate inflammatory reaction in comparison to GII and GIII $(\mathrm{p}<0.05)$. However, GI showed a tendency to an earlier tissue repair. GII and GIII revealed a stronger presence of the granulation tissue and discontinuity of the epithelium in relation to GI (Figure 6). No statistically significant difference was observed among the treatments $(\mathrm{p}>0.05)$ regarding quality, quantity and orientation of collagen fibers.

At day 7, a moderate inflammatory reaction was observed in all specimens, but no statistically significant difference $(\mathrm{p}>0.05)$. The BC-COL hydrogel showed faster epithelial repair than the collagenase and the control groups $(p=0.0364)$. Although the angiogenesis was similar in the three groups, the quality, quantity and orientation of collagen fibers were better for GI and GII in comparison with the group control $(\mathrm{p}=0.0001)$ (Figure 7).

At day 15, a mild inflammatory reaction was observed in all groups, but no statistically significant difference
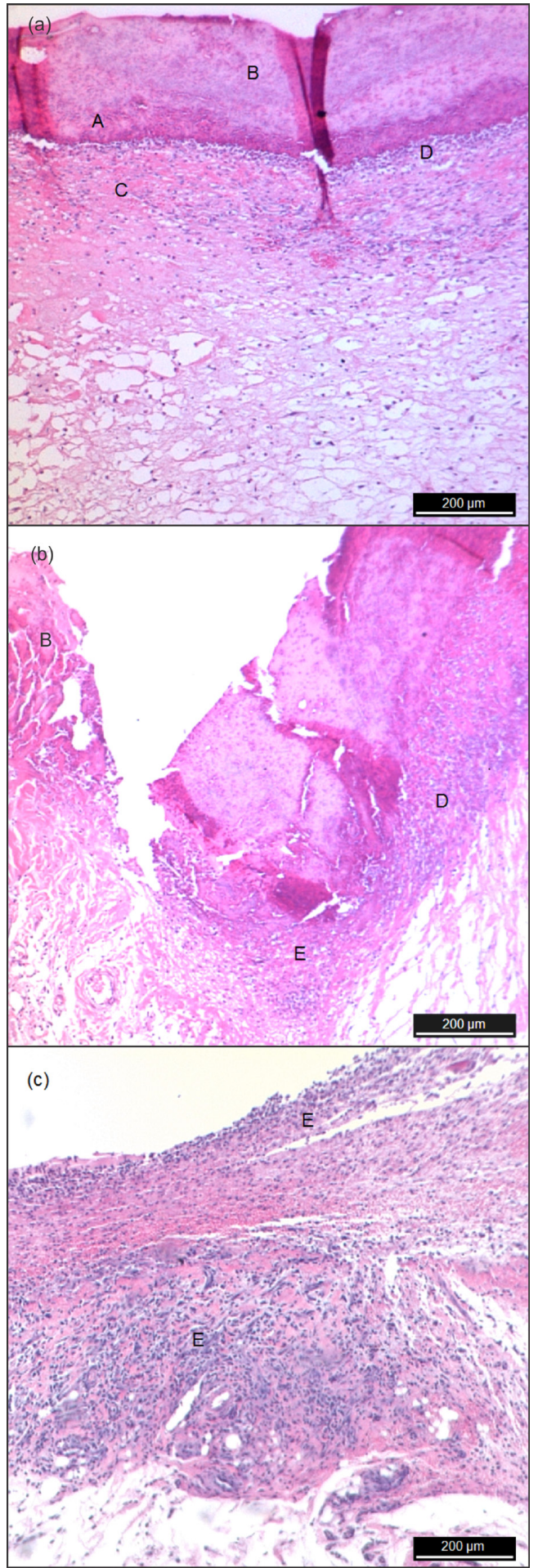

Figure 6. 3-day period, (a) - GI shows early neovascularization, crust and disorganized granulation tissue and moderate inflammatory reaction in the epithelial healing process; (b) - GII shows absence of epithelium, crust and disorganized granulation tissue and mild inflammatory reaction; (c) - GIII shows absence of epithelium, disorganized granulation tissue and mild inflammatory reaction. Inflammatory infiltrates were predominantly composed of polymorphonuclear cells, such as macrophages and neutrophils. Epithelium (A), crust (B), neovascularization (C), inflammatory infiltrate (D) and granulation tissue (E). Staining: H\&E. 


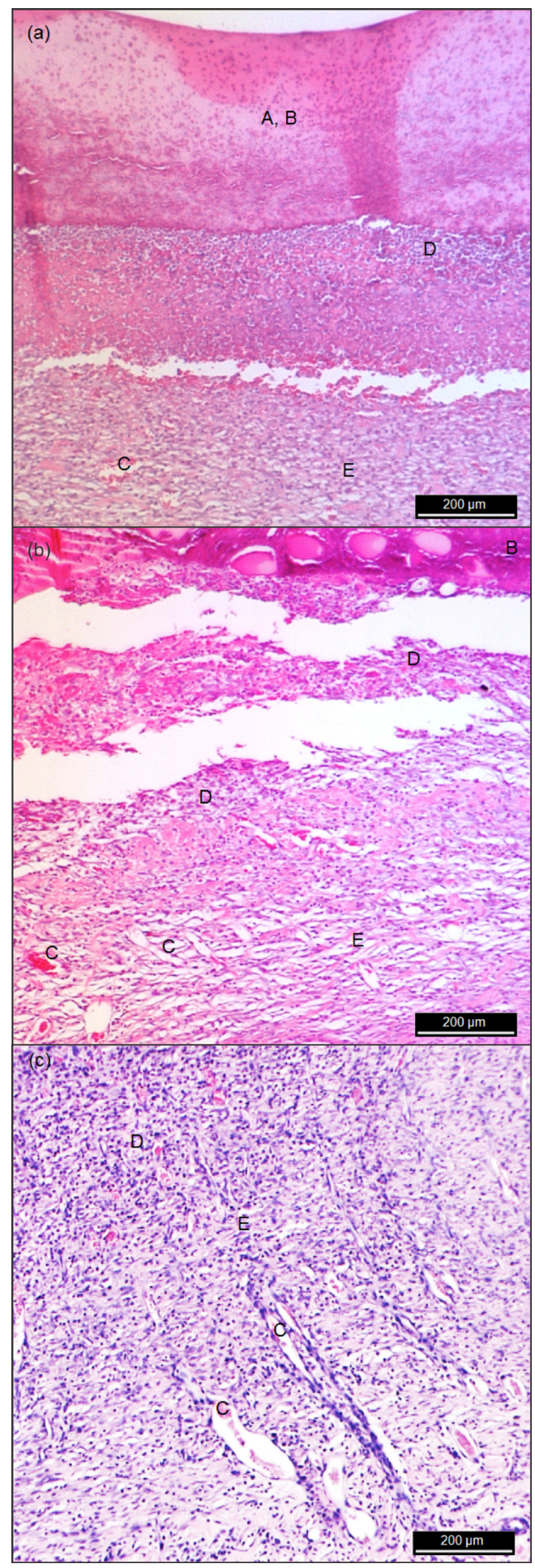

Figure 7. 7-day period, (a) - GI shows early neovascularization, crust, granulation tissue with early organization of collagen fibers and moderate inflammatory reaction in the epithelial healing process; (b) - GII shows absence of epithelium, early neovascularization, crust, moderate inflammatory reaction with early organization of collagen fibers; (c) - GIII shows absence of epithelium, early neovascularization, disorganized granulation tissue and moderate inflammatory reaction. Epithelium (A), crust (B), neovascularization (C), inflammatory infiltrate (D) and organization of collagen fibers (E). Staining: H\&E. $(\mathrm{p}>0.05)$. GI showed completely repaired, thicker and organized epithelium and dermis with organized collagen fibers and tissue rich in blood vessels, in comparison to GII. Although the wounds in GII had been completely repaired, the epithelium showed thinner than that of GI. The epithelial repair in GIII was similar to that of GII; nevertheless, the dermis was still under a repair process with presence of numerous inflammatory cells (Figure 8). A statistically significant difference among the treatments was observed regarding quality, quantity and orientation $(p=0.0001)$ of collagen fibers. Such fibers showed an advanced organization characteristic of normal healing in GI and GII. No statistically significant difference was observed between these two groups ( $\mathrm{p}>0.05$ ).

At day 30, the wounds treated with BC-COL hydrogel showed a higher score and a significant statistical difference $(p<0.05)$ for inflammatory reaction in comparison to GIII and similar results to those of collagenase $(\mathrm{p}>0.05)$. Both epithelium and dermis were completely repaired at day 30 in the 3 groups and displayed characteristics of normality, as organized collagen fibers, numerous blood vessels, glands and hair follicles. The two proposed treatments, i.e., BC-COL hydrogel and collagenase, showed a pattern of similar tissue repair, with dense and oriented collagen fibers, differently from GIII, which showed collagen fibers with a lower degree of organization (Figure 9).

Winter ${ }^{55}$ described the importance of maintaining the humidity of the wound bed for better collagenase and proteases actions. When a wound bed dries, a crust is formed and promotes the migration of the cells to a deeper and humid level in the wound. Vogt ${ }^{56}$ observed the wound healing favored by a humid environment (wounds treated with hydrocolloid dressing) was significantly faster in comparison to dry wounds (wounds treated with sterile gauze). In fact, the BC-COL hydrogel and collagenase ointment used favored a humid environment for the wound bed and promoted an earlier and better tissue repair in relation to the dry wound (control group). However, the BC-COL hydrogel was more efficient than the collagenase ointment. One of the reasons may be the excellent biological properties of $\mathrm{BC}^{30,57,58}$; moreover, the synergism between cellulose and collagen may have favored the conditions for tissue repair.

According to the literature, collagen provides strength and integrity of tissue matrix and promotes homeostasis with breakage and synthesis of type II collagen and epithelialization in the later phase of healing ${ }^{59}$.

The characteristics of bacterial cellulose, as translucent wound dressing and easy application and removal may be advantageous in cases of exacerbated healing (fibrosis) and/or exudate ${ }^{36}$. Bacterial cellulose has been successfully used as a dressing for chronic ulcers, burns, dermabrasion and skin donor areas ${ }^{60,61}$. Barud ${ }^{42}$ developed a wound dressing based on $\mathrm{BC} /$ propolis that proved an effective material for use in infected wounds because of its antibacterial action.

A disadvantage of collagenase ointment is its low adhesiveness on the wound bed, mainly in the first days of treatment, which can limit its use when a bandage cannot 

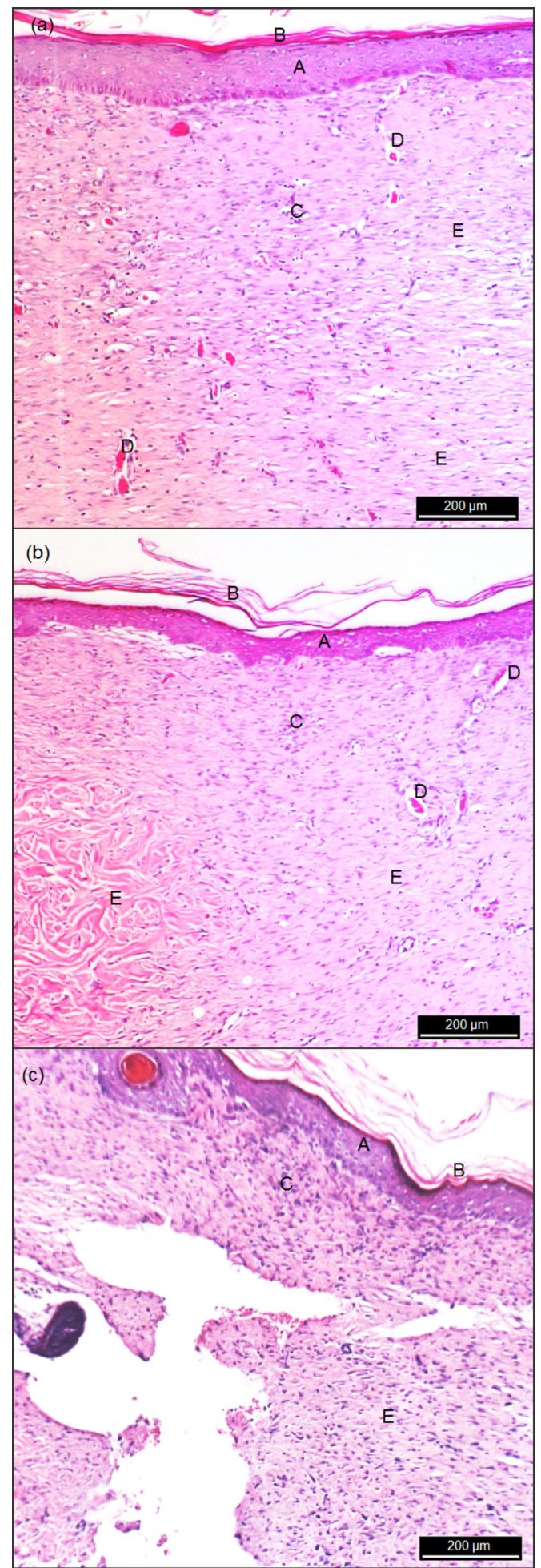

Figure 8. 15-day period, (a) - GI shows complete epithelium and dermis repair, neovascularization, keratin layer and mild inflammatory reaction; (b) - GII shows epithelium in formation and dermis repair, keratin layer, neovascularization and mild inflammatory reaction; (c) - GIII shows re-epithelialization process, keratin layer, disorganized granulation tissue and moderate inflammatory reaction. Epithelium (A), keratin layer (B), inflammatory infiltrate (C), neovascularization (D) and organization of collagen fibers (E). Staining: H\&E.

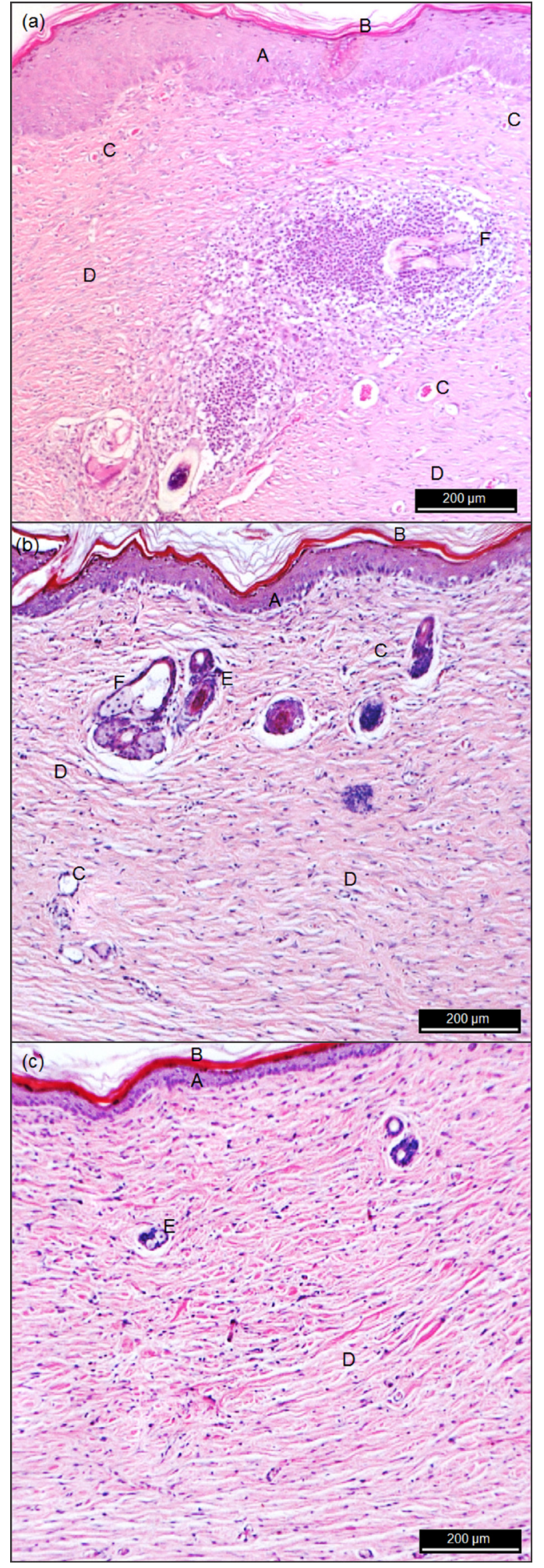

Figure 9. 30-day period, (a) - GI shows complete epithelium and dermis repair, keratin layer and hair follicle; (b) - GII shows complete epithelium and dermis repair with hair follicle and glands; (c) - GIII shows organized tissue, re-epithelialization, keratin layer and presence of glands. Epithelium (A), keratin layer (B), neovascularization (C), organization of collagen fibers (D), glands (E) and hair follicle (F). Staining: H\&E. 
be applied ${ }^{62}$. Therefore, the adhesive property of the BCCOL hydrogel on the wound bed showed advantageous for the treatment of wounds.

\section{Conclusions}

The BC-COL hydrogel showed a potential wound dressing for the treatment of skin wounds, as it yielded more favorable results in comparison to collagenase ointment.

\section{References}

1. Santos VLCG. Avanços tecnológicos no tratamento de feridas e algumas aplicações em domicílio. In: Duarte YA, Diogo MJ. Atendimento domiciliar: um enfoque gerontológico. São Paulo: Atheneu; 2000. p. 265-306.

2. Kangesu T, Navsaria HA, Manek S, Fryer PR, Leigh IM, Green CJ. Kerato-dermal grafts: the importance of dermis for the in vivo growth of cultured keratinocytes. British Journal of Plastic Surgery. 1993;46(5):401-409.

3. Clark RA. The molecular and cellular biology of wound repaired. New York: Plenum Press; 1996.

4. Espey LL. Ovulation as an inflamatory reaction: a hypothesis. Biology of Reproduction. 1980;22(1):73-106.

5. Thakare VM. International standard serial number, promotion of cutaneous wound healing by herbal formulation containing Azadirachta indica and Cynodon dactalon extract in wistar rats. International Journal of Pharmaceutical Research \& Development. 2011;3:(4):80-86.

6. Clark RA. Fibrin and wound healing. Annals of New York Academy of Sciences. 2001; 936:355-367.

7. Lauto A, Mawad D, Barton M, Gupta A, Piller SC, Hook J. Photochemical tissue bonding with chitosan adhesive films. BioMedical Engineering OnLine. 2010;9(47):2-11. doi:10.1186/1475-925X-9-47.

8. Gallant-Behm CL, Yin HQ, Liu S, Heggers JP, Langford RE, Olson ME, Hart DA, Burrell RE. Comparison of in vitro disc diffusion and time kill-kinetic assays for the evaluation of antimicrobial wound dressing efficacy. Wound Repair and Regeneration. 2005;13(4):412-421.

9. Klemm D, Heublein B, Fink HP, Bohn A. Cellulose: fascinating biopolymer and sustainable raw material. Angewandte Chemie International Edition English. 2005; 44(22):3358-3393.

10. Czaja WK, Young DJ, Kawecki M, Brown RM. The future prospects of microbial cellulose in biomedical applications. Biomacromolecules. 2007;8(1):1-12.

11. Sanchavanakit N, Sangrungraungroj W, Kaomongkolgit R, Banaprasert T, Pavasant P, Phisalaphong M. Growth of human keratinocytes and fibroblasts on bacterial cellulose film. Biotechnology Progress. 2006;22(4):1194-1199.

12. Rebello C, Almeida DA, Lima Júnior EM, Dornelas MP. Biofill, um novo substituto de pele: nossa experiência. Revista Brasileira de Cirurgia. 1987;77(6):407-414.

13. Mayall RC, Mayall AC, Mayall LC, Rocha HC, Marques LC. Tratamento das úlceras tróficas dos membros com um novo substituto de pele. Revista Brasileira de Cirurgia. 1990; 80(4):257-283.

14. Fontana JD, de Souza AM, Fontana CK, Torriani IL, Moreschi JC, Gallotti BJ, de Souza SJ, Narcisco GP, Bichara JA, Farah LF. Acetobacter cellulose pellicle as a temporary skin substitute. Applied Biochemistry and Biotechnology. 1990; 24-25:253-264.
Moreover, it is of easy application and adhesiveness on the wound bed and its properties favor the maintenance a humid environment and faster tissue repair in relation to collagenase ointment and the control group.

\section{Acknowledgments}

The authors acknowledge the financial support provided by Brazilian agency CAPES.

15. Jonas R, Farah LF. Production and application of microbial cellulose. Polymer Degradation and Stability. 1998; 59(13):101-106.

16. Wouk AF, Diniz JM, Cirio SM, Santos H, Baltazar EL, Acco A. Membrana biológica (Biofill) - estudo comparativo com outros agentes promotores da cicatrização de pele em suínos: aspectos clínicos, histopatológicos e morfométricos. Archives of Veterinary Science. 1998;3(1):31-37.

17. Andrade FK, Costa R, Domingues L, Soares R, Gama MF. Improving bacterial cellulose for blood vessel replacement: Functionalization with a chimeric protein containing a cellulosebinding module and an adhesion peptide. Acta Biomaterialia. 2010;6(10):4034-4041. DOI: 10.1016/j.actbio.2010.04.023.

18. Yamatogi RS, Rahal SC, Granjeiro JM, Taga R, Cestari TM, Lim AF. Histologia da associação de membranas biológicas de origem bovina implantadas no tecido subcutâneo de ratos. Ciência Rural. 2005;35(4):837-842. http://www.scielo.br/pdf/ $\mathrm{cr} / \mathrm{v} 35 \mathrm{n} 4 / \mathrm{a} 14 \mathrm{v} 35 \mathrm{n} 4$.pdf.

19. Starkweather KD, Lattuga S, Hurst LC, Badalamente MA, Guilak F, Sampson SP, Dowd A, Wisch D. Collagenase in the treatment of Dupuytren's disease: an in vitro study. The Journal of Hand Surgery. 1996;21(3):490-495.

20. Badalamente MA, Hurst LC. Efficacy and safety of injectable mixed collagenase subtypes in the treatment of Dupuytren's contracture. The Journal of Hand Surgery. 2007;32(6):767-774.

21. Frade MA, Assis RV, Coutinho Netto J, Andrade TA, Foss NT. The vegetal biomembrane in the healing of chronic venous ulcers. Anais Brasileiros de Dermatologia. 2012;87(1):45-51. http://dx.doi.org/10.1590/S0365-05962012000100005.

22. Brasileiro BG, Pizziolo VR, Matos DS, Germano AM, Jamal CM. Plantas medicinais utilizadas pela população atendida no "Programa de Saúde da Família", Governador Valadares, MG, Brasil. Revista Brasileira de Ciencias Farmacêuticas. 2008;44(4):329-336. http://dx.doi.org/10.1590/S151693322008000400009 .

23. Dunn DL, Phillips J. Wound closure manual. Minnesota: Ethicon; 2007. http://www.uphs.upenn.edu/surgery/Education/facilities/ measey/Wound_Closure_Manual.pdf

24. Goissis G, Lacerda C, Barbosa MP, Pinatti A. Surface tension controll of collagen biomaterials by the selective hydrolysis of internal carboxyamides of the protein matrix. Revista Brasileira de Engenharia Biomédica. 1999;15(1-2):55-61.

25. Albuquerque-Júnior RL, Barreto AL, Pires JA, Reis FP, Lima SO, Ribeiro MA. Effect of bovine type-I collagen-based films containing red propolis on dermal wound healing in rodent model. International Journal of Morphology. 2009;27(4):1105-1110.

26. ASTM F981-04. Standard practice for assessment of compatibility of biomaterials for surgical implants with respect to effect of materials on muscle and bone. West Conshohocken, PA: ASTM: 2010.

27. O'Brien FJ, Harley BA, Yannas IV, Gibson LJ. The effect of pore size on cell adhesion in collagen-GAG scaffolds. Biomaterials. $2005 ; 26(4): 433-441$. 
28. Saska S, Teixeira LN, de Oliveira PT, Gaspar AM, Ribeiro SJ, Messaddeq Y, Marchetto R. Bacterial cellulose-collagen nanocomposite for bone tissue engineering. Journal of Materials Chemistry. 2012; 22(41):22102-22112.

29. Barud HS, Araújo-Júnior AM, Santos SB, Assunção RM, Meireles CS, Cerqueira DA, Rodrigues-Filho G, Ribeiro CA, Messaddeq Y, Ribeiro SJ. Thermal behavior of cellulose acetate produced from homogeneous acetylation of bacterial cellulose. Thermochimica Acta. 2008; 471(1-2):61-69.

30. Wan YZ, Huang Y, Yuan CD, Raman S, Zhu Y, Jiang HJ, He F, Gao C. Biomimetic synthesis of hydroxyapatite/bacterial cellulose nanocomposites for biomedical applications. Material Science and Engineering. 2007;27(4):855-864.

31. Zhang LJ, Feng XS, Liu HG, Qian DJ, Zhang L, Yu XL, Cui FZ. Hydroxyapatite/collagen composite materials formation in simulated body fluid environment. Materials Letters. 2004; 58(5):719-722.

32. George A, Veis A. FTIRS in $\mathrm{H}_{2} \mathrm{O}$ demonstrates that collagen monomers undergo a conformational transition prior to thermal self-assembly in vitro. Biochemistry. 1991; 30(9):2372-2377.

33. Goissis G, Piccirili L, Goes JC, Plepis AM, Das-Gupta DK. Anionic collagen: polymer composites with improved dielectric and rheological properties. Artificial Organs. 1998; 22(3):203209.

34. Sionkowska A, Wisniewski M, Skopinska J, Kennedy CJ, Wess TJ. Molecular interactions in collagen and chitosan blends. Biomaterials. 2004;25(5):795-801.

35. Song JH, Kim HE, Kim HW. Collagen-apatite nanocomposite membranes for guided bone regeneration. Journal of Biomedical Materials Research. Part B, Applied Biomaterials. 2007;83(1):248257.

36. Panerari AD, Costa HO, Souza FC, Castro M, Silva L, Sousa Neto OM. Avaliação da resposta inflamatória traqueal ao curativo de celulose bacteriana após escarificação cirúrgica em coelhos. Revista Brasileira de Otorrinolaringologia. 2008;74(4):512522. http://oldfiles.bjorl.org/download.asp?id=3696\&nomeA rquivo=74-04-05.pdf.

37. Duynstee ML, Verwoerd-Verhoef HL, Verwoerd CD, Van Osch GJ. The dual role of perichondrium in cartilage wound healing. Plastic and Reconstructive Surgery. 2002; 110(4):1073-1079.

38. Waldorf H, Fewkes J. Wound healing. Advances in Dermatology. 1995;10: 77-96.

39. Inngjerdingen K, Nergård CS, Diallo D, Mounkoro PP, Paulsen BS. An ethnopharmacological survey of plants used for wounds healing in dogoland, Mali, West Africa. Journal of Ethnopharmacology. 2004;92(2-3):233-244.

40. Mensah AY, Houghton PJ, Dickson RA, Fleischer TC, Heinrich $\mathrm{M}$, Bremner P. In Vitro evaluation of effects of two ghanaian plants relevant to wound healing. Phytotherapy Research:PTR. 2006;20(11):941-944.

41. Queen D, Orsted H, Sanada H, Sussman G. A dressing history. International Wound Journal. 2004;1(1):59-77.

42. Barud HS, Araújo-Júnior AM, Saska S, Mestieri LB, Campos JA, Freitas RM, Ferreira NU, Nascimento AP, Miguel FG, Vaz MM, Barizon EA, Marquele-Oliveira F, Gaspar AM, Ribeiro SJ, Berreta AA. Antimicrobial Brazilian Propolis (EPP-AF) containing biocellulose membranes as promising biomaterial for skin wound healing. Evidence-Based Complementary and Alternative Medicine. 20132013:703024. http://dx.doi. org $/ 10.1155 / 2013 / 703024$

43. Falabella AF. Debridement and wound bed preparation. Dermatologic Therapy. 2006; 19(6):317-325.

44. Eccleston GM. Wound dressings. In: Aulton ME. Pharmaceutics: The science of dosage form design. 3rd ed. United Kingdow: Churchill Livingstone; 2007. p. 264-271.
45. Kickhöfen B, Wokalek H, Scheel D, Ruh H. Chemical and physical proprieties of a hydrogel wound dressing. Biomaterials. 1986;7(1):67-62.

46. Araújo CF, Souza Filho ZA, Greca FH, Guerreiro MH, Leite AL, Mansur AE, Kantor DC, Nassif AE. Efeitos do agarol e do trigliceril sobre a cicatrização de pele: estudo experimental em ratos. Acta Cirúrgica Brasileira. 1994;13(4):232-237. http:// dx.doi.org/10.1590/S0102-86501998000400006.

47. Anderson JM, Langone JJ. Issues and perspectives on the biocompatibility and immunotoxicity evaluation of implanted controlled release systems. Journal of Controlled Release. 1999;57(2):107-113.

48. Sun G, Zhang X, Shen YI, Sebastian R, Dickinson LE, Talbot KF, Reinblatt M, Steenbergen C, Harmon JW, Gerecht S. Dextran hydrogel scaffolds enhance angiogenic responses and promote complete skin regeneration during burn wound healing. Procedings of the National Academy of Sciences of the United States of America. 2011;108(52):20976-20981.

49. Jayakumar R, Prabaharan M, Kumar PT, Nair SV, Furuike $\mathrm{T}$, Tamura H. Novel chitin and chitosan materials in wound dressing. Biomedical Engineering, Trends in Materials Science. 2011:3-24. http://cdn.intechopen.com/pdfs-wm/12794.pdf.

50. Wichterle O, Lim D. Hydrophilic gels for biological use. Nature. 1960;185:117-118.

51. Debra JB, Cheri O. Wound healing: Technological innovations and market overview. 1998; 2:1-185.

52. Morgan DA. Wound management products in the drug tariff. The Pharmaceutical Journal. 1999;263(7072):820-825.

53. Sevastjanova NA, Mansurova LA, Dombrovska LE, Slutskii LI. Biochemical characterization of connective tissue reaction to synthetic polymer implants. Biomaterials. 1987;8(4):242-247.

54. Sanchez F. Avaliação do processo de reparação tecidual em úlceras crônicas utilizando curativos de celulose bacteriana associados ou não a laserterapia. [dissertação] São Carlos: Universidade de São Paulo; Escola de Engenharia de São Carlos; 2012.

55. Winter GD. Formation of the scab and the rate of epithelialization of superficial wounds in the skin of the young domestic pig. Nature. 1962;193:293-294.

56. Vogt PM, Andree C, Breuing K, Liu PY, Slama J, Helo G, Eriksson E. Dry, moist and wet skin wound repair. Annals of Plastic Surgery. 1995;34(5):493-500.

57. Hoenich N. Cellulose for medical applications: past, present, and future. BioResources. 2006;1(2):270-280.

58. Osman AS, Souza FC, Dolci JE. Estudo experimental sobre a aplicação de película de celulose (Bionext ${ }^{\circledR}$ ) em área cruenta de ressecção de concha nasal de coelhos. Acta ORL: Técnicas em Otorrinolaringologia. 2007;25(4):304-311.

59. Gupta A, Kumar R, Upadhyay NK, Surekha P, Roy PK. Synthesis, characterization and efficacy of chemically crosslinked pva hydrogels for dermal wound healing in experimental animals. Journal of Applied Polymer Science. 2009;111(3):1400-1408.

60. Costa HO, Souza FC. Avaliação da regeneração tecidual da pele de porco submetida a lesão térmica seguida de colocação de Biotissue ${ }^{\circledR}$. Acta ORL:Técnicas em Otorrinolaringologia. 2005; 23(3):23-27.

61. Czaja W, Krystynowicz A, Bielecki S, Brown Jr. RM. Microbial cellulose-the natural power to heal wounds. Biomaterials. 2006;27(2):145-151.

62. Rahal SC, Rocha NS, Blessa EP, Iwabe S, Crocci AJ. Pomada orgânica natural ou solução salina isotônica no tratamento de feridas limpas induzidas em ratos. Ciência Rural. 2001; 31(6):10071011. http://dx.doi.org/10.1590/S0103-84782001000600015. 